Acta Universitatis Wratislaviensis • No 3982

Literatura i Kultura Popularna XXV, Wrocław 2019

https://doi.org/10.19195/0867-7441.25.12

\author{
Wojciech Kajtoch \\ ORCID: 0000-0003-3000-2384 \\ Uniwersytet Jagielloński
}

\title{
Stanisława Baczyńskiego teoria kryminału
}

Słowa kluczowe: powieść kryminalna, literatura polska przed 1939, literatura europejska przed 1939, teoria powieści, literatura awangardowa

Keywords: criminal novel, Polish literature before 1939, European literature before 1939, novel theory, literary avant-garde

Stanisław Baczyński (maj 1890-lipiec 1939), ojciec powszechnie znanego poety Krzysztofa Kamila, funkcjonuje w historii literatury polskiej jako lewicowy krytyk literacki lat trzydziestych. Zainteresowanie nim nie było i nie jest duże. Przed wojną nieczęsto go zauważano, po wojnie przypomniano go w latach sześćdziesiątych. Generalnie jednak peerelowskie względy cenzuralne nie sprzyjały głębszemu omówieniu jego sylwetki i poglądów, funkcjonował w polskiej historii literatury jako ktoś bardzo podobny do Ignacego Fika, czy też — z innej strony — do Władysława Broniewskiego.

Pierwsze podobieństwo akcentowano przy omawianiu jego poglądów na temat społecznej roli literatury, zwłaszcza wskazując na jego myślowy dorobek lat trzydziestych. Można go uznać za zwolennika realizmu, więc — zapewne w hipotetycznej przyszłości, która by go czekała, gdyby nie umarł tak wcześnie, „wielkiego realizmu” Jana Kotta czy nawet socjalistycznego realizmu, jeśli na przykład zacytować jego słowa z Rzeczywistości i fikcji,,wydanej”" w 1939 roku:

Naprawdę istotne jest to, kim jest człowiek, co robi, gdzie pracuje, z kim współdziała, jaką ma ideologię i do czego dąży, słowem wartość dynamiczna człowieka jako członka pewnej zbiorowości. Nie adres domu, w którym ktoś mieszka, ale adres fabryki, biura i organizacji, do której jednostka należy, określa ją i w tym znaczeniu środowisko charakteryzuje

${ }^{1}$ Stanisław Baczyński zmarł w lipcu, gotowy nakład spłonął, przetrwało parę egzemplarzy obszerne fragmenty wznowiono w wyborze Andrzeja Kijowskiego (S. Baczyński, Pisma krytyczne: Wyboru dokonat i wstępem poprzedził Andrzej Kijowski, Warszawa 1963). 
człowieka, wyznacza mu realne miejsce w życiu kolektywnym. Poza tym środowisko nie tylko wyjaśnia $\mathrm{i}$ usprawiedliwia rację bytu jednostki w powieści, lecz działa też jako zbiorowość czynna, przez kontrast albo zgodność z działaniem jednostki².

Ponieważ na początku lat trzydziestych deklarował się jako (nieco krytyczny) zwolennik ugrupowania Nowyj Lef i literatury faktu ${ }^{3}$, to rzeczywiście jego ostatnie ideowe przygody zdają się typowe dla przedwojennych, radykalizujących się, lewicowych polskich inteligentów w rodzaju Adama Ważyka, Aleksandra Wata, Brunona Jasieńskiego itp.

Patrzenie jednak na Baczyńskiego w ten sposób nie wydaje się całkiem adekwatne, bo po pierwsze, na propozycje typu rezygnacja z obywatelstwa polskiego i objęcie wykładów w Moskwie zareagował negatywnie ${ }^{4}$, a po drugie, jego lewicowa radykalizacja przebiegała dość wolno. Na przykład jego Literatura w Z.S.R.R ... z 1932 roku owszem starała się tę literaturę opisać, ale ocenę stawiała jej niską ${ }^{5}$.

Trudno też widzieć w nim jedynie piłsudczyka, który „obraził się” na Komendanta, kiedy ten przestał poważnie traktować idee lewicowe. Baczyński, jeden z dowódców żandarmerii Strzelca, oficer kierujący polskimi grupami dywersyjnymi w czasie trzeciego powstania śląskiego, szef ochrony polskiej delegacji tajnie w 1919 roku negocjującej z bolszewikami ${ }^{6}$ naprawdę dużo wiedział i musiał się orientować $\mathrm{w}$ mechanizmach prowadzenia państwowej polityki. Trudno więc w jego decyzji opuszczenia wojska i zostania (lewicującym) literatem dostrzegać tylko dowód fascynacji myślą lewicową, socjalistyczną, a później może i komunistyczną... Ponadto nie wiemy przecież, jak przebiegałyby jego wojenne i powojenne losy. Ogólnie widzenie w nim tylko kogoś podobnego do Broniewskiego, a zatem zawiedzionego legionisty, który związał się z lewicą, wydaje się ryzykowne.

2 S. Baczyński, op. cit., s. 299. We wszystkich cytatach zachowano oryginalną pisownię.

3 Por. S. Baczyński, Literatura w Z.S.R.R., Kraków-Warszawa 1932, s. 149-161.

${ }^{4}$ Por. M. Stępień, Obowiązek i prawo oceny (o Stanisławie Baczyńskim), „Zdanie” 2015, nr 3-4, s. 93.

${ }^{5}$ Kijowski tak pisze o marksizowaniu Baczyńskiego: „nieobca jest [mu] myśl marksistowska, daleki jednak jest, przynajmniej początkowo, od przyjęcia jej w całości [...] socjalizm jest dla Baczyńskiego następstwem historycznym, kolejną strukturą, nie zaś rezultatem walki klasowej” (A. Kijowski, Wstęp, [w:] S. Baczyński, Pisma krytyczne..., s. 13-14). Baczyński pisze o literaturze ZSRR, że ,pod względem formy trudno dopatrzyć się w dzisiejszej literaturze rosyjskiej przełomów rewelacyjnych” (S. Baczyński, Literatura w Z.S.R.R..., s. 5), zauważa szerzący się ,prymitywizm umysłowy w ocenie zjawisk życiowych, szablon i schematyczność w stosowaniu teorji marksizmu, wpajanej dogmatycznie młodzieży, za pomocą uproszczonych formułek. Zwężony bowiem do ostateczności materializm daje przy całej swej istotnej rozciągliwości i plastyczności djalektycznej pole do nadużyć i fałszów” (ibidem, s. 69), pisze o „nieprzygotowaniu Lenina do rozwiązania problemu przyszłej sztuki (ibidem, s. 106), „snobizmie proletarjackim” (ibidem, s. 122). Osąd Baczyńskiego jest generalnie krytyczny i nie dziwi fakt niewznawiania książki po 1945 roku, mimo całej jej „lewicowości”.

6 Zob. M. Stępień, op. cit., s. 84. 
Najdziwniejsze jednak dla znanych mi literaturoznawczych interpretatorów myśli Baczyńskiego, a przy tym najbardziej dla mnie tu interesujące są jego fascynacje literaturą popularną, zwłaszcza kryminałem.

Dla historyków literatury zainteresowanych krytykiem były one czymś bardzo zaskakującym. Przywoływany Marian Stępień w ogóle o nich w cytowanym tekście nie wspominał. Konsekwentnie upatrując w Baczyńskim myśliciela lewicowego, pominął temat - jak wiadomo zwolennicy literatury marksistowsko-lewicowej nie zajmowali się rozrywkowymi gatunkami jako za mało realistycznymi, a nawet krytykowali je jako przejaw kapitalistycznej dekadencji.

Z kolei autor wyboru pism krytycznych Baczyńskiego Andrzej Kijowski Powieść kryminalna wymienił i pochwalił, ale nie znalazł jakiejś jasnej genezy nietypowych, kryminałoznawczych zainteresowań krytyka. Pisał:

Aktem przekory jest książka o romansie kryminalnym. Jest ona aktem przekory wobec oficjalnej hierarchii gustów podobnie jak Irzykowskiego książka o kinematografii [...] włożył w nią Baczyński najwięcej siebie. Wolny od serwitutów filozofa kultury, które sobie narzucił w innych pracach, tu, na terenie przez nikogo nie zbadanym, nie obstawionym przez teoretyków, Baczyński, po raz pierwszy i bodaj że jedyny, buduje własne formuły losu ludzkiego, psychologii, etyki. Jego formuły o zbrodni i karze, o tragiczności etc. są zaskakujące, mają jakieś własne, autentyczne ciepło ${ }^{7}$.

Jakiegoś szerszego komentarza jednak nie da1 ${ }^{8}$.

W istocie Powieść kryminalna jest dość tajemniczą broszurą Baczyńskiego. Wyszła w Wydawnictwie Literacko-Naukowym w 1932 roku, wtedy kiedy (w tejże oficynie) Literatura $w$ Z.S.R.R., ale musiała ona być napisana parę lat wcześniej. Wydaje się, że Baczyński, pisząc tę drugą, już się powieścią kryminalną nieomal nie interesował, skoro nie zauważył „czerwonego Pinkertona”, a jako przykład rozwoju powieści o zbrodni w Rosji porewolucyjnej dał utwory w zasadzie obyczajowe, jako kontrast przedrewolucyjny zaś opisał przede wszystkim utwory Dostojewskiego, zasadniczo głosząc te same tezy co w Powieści kryminalnej. Ogólnie

${ }^{7}$ A. Kijowski, op. cit., s. 16.

${ }^{8} \mathrm{Na}$ S. Baczyńskiego zwrócił natomiast uwagę filozof estetyk Bohdan Dziemidok. Uważał za istotną jego refleksję o funkcji katarktyczno-kompensacyjnej kryminału: „,funkcja katarktyczno-kompensacyjna łączy się również z treścią utworów, w szczególności zaś tych, które malują obraz człowieka, prezentują jego najróżnorodniejsze problemy, przedstawiają jego losy i najróżnorodniejsze sytuacje życiowe; [m.in.] stwarza warunki do projekcji i częściowego wyładowania własnych niepokojów, kompleksów oraz impulsów, które niewyładowane mogłyby działać destrukcyjnie na jednostkę, a ujawnione w bardziej bezpośredniej postaci byłyby niebezpieczne i szkodliwe dla społeczeństwa” (B. Dziemidok, Czy sens i znaczenie współczesnej sztuki popularnej sprowadza się do jej wartości rozrywkowych?, „Estetyka i Krytyka” 2011, nr 1 (20), s. 61). Dziemidok uznał Baczyńskiego za ważnego w Polsce swoich czasów przedstawiciela umiarkowanego relatywizmu estetycznego (idem, Teoria przeżyć $i$ wartości estetycznych $w$ polskiej estetyce dwudziestolecia międzywojennego, Warszawa 1980, s. 302 n.).

$9 \mathrm{Na}$ temat owego fantastyczno-kryminalnego kierunku rozwijającego się w latach dwudziestych w Rosji zob. W. Kajtoch, Bracia Strugaccy. Wydanie drugie, uzupetnione, Stawiguda 2016, s. $66-67$. 
o roli kryminału w Literaturze $w$ Z.S.R.R. raczej się nie wypowiedział ${ }^{10}$, chyba więc stracił nim zainteresowanie.

Natomiast w Losach romansu, bardzo solidnej analizie rozwoju gatunku powieściowego w Polsce od końca XVIII wieku, wydanej w 1927 roku (ukończonej w 1925), w której pisał między innymi o polskiej powieści oświeceniowej, sentymentalnej i początków romantyzmu (Ignacy Krasicki, Fryderyk Skarbek, Julian Ursyn Niemcewicz, Franciszek Wężyk, Feliks Bernatowicz i inni), tak wypowiadał się o utworach słabszych, które — jego zdaniem — charakteryzują

znikomość spraw życiowych i przygnębienie, [które] nie budzą żywszej potrzeby uogólnień filozoficznych (jak u Balzaka), redukując znaczenie powieści do lekkiej strawy rozrywkowej. Same tytuły magazynów i czasopism, w których drukują się te utwory („Rozrywki”, „Moje Rozrywki" itp.) redukują romans w literaturze do salonu i gotowalni, z których pragnie on wyprzeć modne powieści francuskie ${ }^{11}$.

Można z tego fragmentu wnioskować, że w okresie pisania Losów romansu o literaturze popularnorozrywkowej nie miał jeszcze dobrego zdania.

Wygląda więc na to, że rozrywkowość, popularność, przeznaczenie dla niewyrobionego czytelnika wzorem wielu krytyków traktował wówczas jako grzech $\mathrm{i}$ w trywialnej literaturze kryminalnej niczego istotnego nie poszukiwał. Ba! W ogóle jej nie zauważał, bo w Losach romansu zajmował się głównie powieścią poważną, romantyczną, pozytywistyczną, młodopolską i (sobie) współczesną (Józef Ignacy Kraszewski, Henryk Rzewuski, Zygmunt Kaczkowski, Eliza Orzeszkowa, Bolesław Prus, Henryk Sienkiewicz, Władysław Reymont, Stefan Żeromski, Stanisław Brzozowski, Wacław Berent, Andrzej Strug itp.), potrafiąc w sposób całkiem profesjonalny opisać przemiany jej formy. A gatunkami „niższymi” w rodzaju kryminału w ogóle się nie zajmował.

Dziś podziw budzi zwłaszcza jego umiejętność dokonywania analiz narracji, bardzo wyprzedzająca standardy przedwojenne. Oto próbka jego stylu — opis

10 Określenie „romans kryminalny” padło jeden raz. Miał to być jeden z dwóch gatunków świadczących o tym, że literatura Zachodu nie jest całkowicie nieprzygotowana do pojęcia tematów związanych ze zmianami społecznymi po Wielkiej Wojnie. „Na rynku literackim Europy narastają i przerastają go coraz częściej książki kryzysowe, bez problemu, książki narkotyki pochłaniane przez sybarytów mieszczańskich, dalekie od rzeczywistości. Degeneracja ustroju społecznego sprowadza tu każdy problem do zera, pustki i filozofji okolicznościowej, mniej więcej oklepanej. Jedynemi zaś momentami silnemi są dzieła negatywne, odkrywające rozkład u korzeni. Ze świata teraźniejszego można się dziś tylko śmiać w satyrze [...], łamać ręce nad nim w rozpaczy [...] słowem wzruszać go poprzez wystawianie mu świadectwa nędzy i upadku. [...] Jeżeli zastosowalibyśmy do literatury tezę, iż sztuka stanowi dopełnienie i spełnienie pragnień i perspektyw, które w realnem życiu nie dadzą się urzeczywistnić, musielibyśmy stwierdzić, że współczesne szczyty literatury europejskiej spełniają to zadanie w małym stopniu z wyjątkiem literatury kryminalnej i egzotycznej. Romans kryminalny i reportaż egzotyczny coraz częściej zaczyna spełniać funkcje odpowiednika potrzeb czytelniczych ogółu, staje się zadośćuczynieniem głodu wyobraźni, lub w najlepszym razie, na wyższym stopniu kultury czytelników, wyrównaniem potrzeby nie zaspokojonej przez kulturę artystyczną" (S. Baczyński, Literatura w Z.S.R.R..., s. 85-86).

11 S. Baczyński, Losy romansu, Warszawa 1927, s. 29. 
cech charakterystycznych ,impresjonizmu literackiego"12 swoistego dla powieści młodopolskiej:

Liryzm nastrojowy, giętki, podatny do nadużyć, szerzący nieraz wprost epidemię kabotyństwa przeniknął wszystkie kierunki literackie modernizmu, a przez swą ekspresyjność zyskał łatwo przewagę nad opowiadaniem i opisem, spychając je do akcesorjów podrzędnych. W związku z tem maleje ciągłość dramatyczna zdarzeń, rośnie pogarda dla wątku przyczynowego akcji powieściowej, słowem ujawnia się zniecierpliwienie w stosunku do faktów i rzeczy zmysłowych, nawet w tematach historycznych (Popioły). Punkt ciężkości fabuły przenosi się na związki psychiczne. Dawną przyczynowość naturalistyczną, realną, wypiera motyw psychologiczny, dla którego fakty są tylko symbolami ([Stanisław] Przybyszewski). Krańcowa zaś indywidualizacja tematów psychologicznych, wysnutych z introspekcji i samoobserwacji twórców, obniża zainteresowanie sprawami życia zewnętrznego, skupia większą uwagę na kunszcie literackim i problemach jednostkowych. Skutkiem tego przyczynowy tok zdarzeń uległ rozbiciu na fragmenty, których osnowę stanowiły perypetje duchowe autora, a nie konkrety (Ludzie bezdomni). Przyroda i środowisko społeczne uległy tu prześwietleniu impresjonistycznemu, opis zaś był rezultatem nie obserwacji drobiazgowej, ale doraźnego wrażenia, fragmentów przeżycia ${ }^{13}$.

Przynajmniej zależność między psychologizacją (w dzisiejszej terminologii — personalizacją) narracji a rozkładem fabuły została tu celnie uchwycona. Jak widać, Michał Głowiński czy Kazimierz Bartoszyński mieliby możliwość wskazywania kolejnego ze swoich poprzedników (o ile oczywiście Baczyńskiego czytali), gdyż wydaje się on całkiem sprawnym jak na swoje czasy teoretykiem powieści.

W 1927 roku Baczyński wydaje przekład zbioru felietonów Gilberta Keitha Chestertona: Obrona niedorzeczności, pokory, romansu brukowego i innych rzeczy wzgardzonych, z których jeden poświęcony jest powieści kryminalnej i - jak sądzę - wyłącznie ten tom ${ }^{14}$ stoi u genezy interesującej nas tutaj publikacji.

Myślę więc, że Baczyński pisze Powieść kryminalna pod koniec lat dwudziestych, kiedy nie zainteresował się jeszcze poważnie rosyjską literaturą porewolucyjną i pozostawał głównie zwolennikiem awangardy: przede wszystkim ekspresjonistycznej, poniekąd futurystycznej, a nawet skamandryckiej.

12 Ibidem, s. 85.

13 Ibidem, s. 85-86.

14 G.K. Chesterton, Obrona niedorzeczności, pokory, romansu brukowego i innych rzeczy wzgardzonych. Zoryginału angielskiego, z upoważnienia autora przełożyt Stanisław Baczyński, Warszawa 1927 (zbiór oryginalny: The Defendant, przedrukowany wedle wydania z 1901 roku, jest dostępny na stronie https://www.gutenberg.org/files/12245/12245-h/12245-h.htm, dostęp: 25.07.2018). W tym tomie na s. 136-142 znajduje się felieton: Obrona detektywnych powieści (org. A Defence of Detective Stories, „The Speaker" 1901, https://www.pdcnet.org/chesterton/content/chesterton_2011_0037_40545_0021_0023, dostęp: 25.07.2018). Przestarzałe dziś określenie „powieść detektywna” (sam Baczyński — jak wiadomo — pisał o powieści kryminalnej) obecne było w polszczyźnie przynajmniej do 1958 roku — zob. J. Krzyżanowski: Rzędzian i Sherlock Holmes czyli o powieści detektywnej, [w:] idem, Szkice folklorystyczne, t. 2. W kręgu pieśni. W krainie bajki, Kraków 1980, s. 191-200. 
Można więc - i tak zrobię — potraktować Powieść kryminalna jako owoc myślenia awangardowego swoich czasów, z jego głównymi tezami, zakładającymi, że:

1. Po pierwszej wojnie światowej świat zmienił się diametralnie, powstała nowa cywilizacja, pojawił się nowy czytelnik, zaszły poważne zmiany w myśleniu prostych mas, które - mimo że zmieniło się ich życie — skazane są na starą, przedwojenną literaturę, zaspokajającą tylko stare potrzeby mieszczaństwa i inteligencji.

2. Powinna zatem powstać literatura podejmująca nowe tematy i zaspokajająca niedawno powstałe potrzeby. Powinni ją wymyślić pisarze piszący „po nowemu" i zdolni dostrzegać współczesne cywilizacyjne zjawiska - powstałe wskutek rozwoju techniki i masowych społeczeństw.

3. To zaspokojenie ostatnio powstałych potrzeb powinno się odbyć głównie poprzez przemianę formy dzieł. Diametralnie nowe zjawiska można dostrzec i uzmysłowić odbiorcy tylko za pomocą formalnych zmian w samej konstrukcji dzieł. Utwory dostrzegające nową, zmienioną istotę rzeczywistości zyskały tę zdolność dzięki zastosowaniu przez artystę nieznanych lub lekceważonych dotychczas chwytów konstrukcyjnych, formalnych.

4. Rozwijanie formy uprawianej twórczości jest też realizacją misji społecznej. Artysta - dzięki zastosowaniu nowych chwytów formalnych i konstrukcyjnych podczas tworzenia - buduje dzieło będące świadectwem nowego spojrzenia na rzeczywistość, pozwalające dostrzec rzeczy dawniej niewidziane, a więc — w ostatecznym rozrachunku — optymalizację zachowań odbiorcy stojącego wobec wyzwań zmiennej rzeczywistości. Odbiorca, jeśli takie myślenie w dziele dostrzeże i je z niego „wyekscerpuje” — „zarazi się nim od artysty” i w rezultacie będzie mógł otaczającą go rzeczywistość lepiej zrozumieć. Sztuka, popularna czy też „dla dwunastu" ${ }^{15}$, pełni więc istotną funkcję społeczną, wychowuje.

Myślenie takie, obecne w zasadzie we wszystkich awangardowych ruchach dwudziestolecia, a najpełniej w pismach Tadeusza Peipera (Baczyński najprawdopodobniej „Zwrotnicy” albo nie czytał, albo się z tą lekturą nie zdradził, przynajmniej w pismach, które przeczytałem na potrzeby tego szkicu), nie było obce autorowi Powieści kryminalnej. Dał mu wyraz w pomniejszych pismach lat dwudziestych, a przede wszystkim w ostatnim rozdziale Losów romansu. Stawiał tam konkretne postulaty. Wymienię je w punktach ${ }^{16}$ :

15 Światopogląd twórcy awangardowego szkicuję głównie na podstawie charakterystyki myślenia Tadeusza Peipera stworzonej przez Stanisława Jaworskiego (S. Jaworski, Wstęp, [w:] T. Peiper, Dzieła wybrane. Opracowat Stanisław Jaworski, Wrocław-Kraków 1979, s. III-LXXX), o sensie tworzenia „sztuki dla dwunastu”, czyli poezji tak trudnej, że jej zasady zrozumieją tylko nieliczni pośrednicy, którzy będą w stanie jej wersję ułatwioną rozpowszechnić, zob. s. XXII-XXIV. Porównaj także W. Kajtoch, Presymbolizm, symbolizm, neosymbolizm... Rzecz o czytaniu wierszy, Kraków 1996, s. 48-52. Oczywiście zaznaczam, że Baczyński, zainteresowany literaturą popularną, nie popierał zasady tworzenia „sztuki dla dwunastu”.

${ }^{16}$ Korzystam z rozdziału piątego Losów romansu, ale czasem sięgam i do wcześniejszych pism, jeśli cechy awangardowego myślenia S. Baczyńskiego są tam lepiej widoczne (na przykład 
1. Współczesna Polska nie potrzebuje już literatury tylko patriotycznej i narodowej, jej sztuka ma „oddychać wolnem powietrzem Europy i [stanowić] teren nieskrępowanych wysiłków, nowa sztuka powinna zapowiadać raczej wielostronny panideizm"17. Ogólnie: nowe czasy potrzebują nowej sztuki.

2. Nowa sztuka musi być oparta na nowych zasadach konstrukcyjnych i estetycznych, jej funkcja społeczna ma polegać na zaspokajaniu potrzeb estetycznych, sztuka to „powszechne narzędzie kształcenia duszy” 18 , „równe pod względem znaczenia z nauką"19. Stąd istotna społeczna funkcja artysty.

3. „Nie dążność przeto, ani służebnictwo decyduje o wartości nawet społecznej utworu, tylko i wyłącznie jego walory estetyczne, kompetentne. Artysta spełnia swój społeczny obowiązek przez stwarzanie walorów formy, czyli artystyczne celowe wyładowanie energii po linii sprawdzianów estetycznych" ${ }^{20}$. Mówiąc przy tym o ,potrzebach estetycznych”, miał na myśli „potrzebę wzruszeń wyobraźni i zmysłów"21.

4. Aby swój obowiązek wypełniać, artysta powinien być wolny. Nie tylko należy więc wyzwolić sztukę „spod wpływów mieszczaństwa"22, ale też pamiętać, że „rewolucjonizm sztuki ma swoje własne fermenty o charakterze społecznym, niezależne od dyktatury klasowej [a zatem] Uzależnianie przyszłego rozwoju sztuki od zwycięstwa socjalizmu należy przypisać niskiej kulturze teoretyków i doktrynerów”23, „rola pisarzy i krytyków w rzeczpospolitej sowieckiej zeszła do niewolnictwa" 24 .

Jak widać, nie był jeszcze Baczyński zbyt zafascynowany literaturą radziecką i jej podobnymi.

Inne jego uwagi o sytuacji nowej, powojennej, młodej literatury polskiej zaczerpnąłem z fragmentów niektórych esejów przedrukowanych w wyborze Kijowskiego. Zasadniczo więc sądził, że w latach dwudziestych w Polsce i Europie:

— sztuka nowoczesna ,poszukuje nowego źródła, nowego terenu, słowem, nowej treści i formy swojego wyrazu" 25 ;

— kreując bohatera, trzeba „budować most między chaosem kultury pojęć i symbolów, a elementami życia, jak instynkt i intuicja"26.

Syty Paraklet i głodny Prometeusz. Najmłodsza poezja polska; Sztuka walczaca - dane bibliograficzne w stosownych przypisach i bibliografii).

17 S. Baczyński, Losy romansu, s. 107.

18 Ibidem, s. 108.

19 Ibidem.

20 Ibidem, s. 109.

21 Ibidem.

22 Ibidem, s. 111.

23 Ibidem, s. 112.

24 Ibidem, s. 113.

25 Cyt. za: S. Baczyński, Sztuka walcząca, [w:] idem, Pisma krytyczne..., s. 96 (przedruk pracy wydanej w 1923 roku).

26 Ibidem, s. 99. 
— „Sztuka nowa pragnie zniweczyć swą łączność z tradycją, niby parta nieokreśloną dotychczas potrzebą zerwania ze światem dawnym nie tylko w pobudkach, lecz i w formie artystycznego wyrazu"27;

— „Sztuka winna zostać tworem, bezwzględnie wynikającym ze struktury psychicznej i »świadomości twórcy, czyli winna mieć charakter ekspresji«"28; „nie usiłuje naśladować rzeczywistości za pomocą technicznego rzemiosła, wyzwala natomiast twórczą energię artysty, stwarza świat zgoła nowy, wprowadza do szeregu faktów fakty nowe" 29 ;

— „Całkowity rozdział formy od treści może się odbyć tylko w sferze abstrakcyjnego myślenia" ${ }^{30}$;

- „Rodzi się tendencja do określenia stanowiska sztuki wobec społeczeństwa, potrzeba jej upowszechnienia z jednej, a przezwyciężenie filisterstwa z drugiej strony"31;

— ,[Sztuka] stanowi w postaci swej materialnej wytwór równorzędny z cywilizacją i kulturą umysłową, a tym samym w zbiorowiskach ludzkich stać się winna upowszechnionym motorem życia, jego dynamicznym pierwiastkiem"32;

— „Sztuka nie stanowi wytworu żadnej doraźnej warstwy społecznej, wieku ani okresu, jest tak samo trwała jak byt ludzki i nie powinna opierać swojego istnienia na służebności wobec innych przejawów życia. Artysta tym samym przestaje być luksusem społecznym, istotą drugorzędną, względnie tylko potrzebną - zaczyna być twórcą nowych prawd, ważnym na równi z reformatorami i wychowawcami"33;

— „Poeta nie rekonstruuje za pomocą kategorii przyczynowości ładu w przyrodzie, lecz konstruuje świat według planu duszy własnej, widzi go w takim samym ruchu jak istotę żywą,"34;

— „Nowa poezja to nie dziwactwo, lecz symptom, znak nadchodzącej przemiany wartości, której miarą nie będzie komunał, lecz ruch i postęp"35;

27 Ibidem, s. 101.

28 Ibidem, s. 111.

29 Ibidem, s. 114.

30 Ibidem, s. 120.

31 Ibidem, s. 126. Zwróciłem uwagę na ten cytat, wskazuje on bowiem wroga nowoczesnej sztuki - filistra, mieszczanina, kogoś tradycyjnie myślącego, który jej nie rozumie, a w szczególności nie wie o nowej roli artysty, ceni ujęcia stereotypowe — to znaczy realistyczne — i zupełnie nie rozumie, że czasy się zmieniły. To jednak nie jest dla Baczyńskiego przeciwnik po marksistowsku rozumiany, całkowicie się mieści w paradygmacie modernistycznym. To filisterstwo stoi naprzeciw artystów, którzy mogą swoją sztuką wychować nowego człowieka, dla którego „Sztuka stanie się koniecznością życia" (ibidem, s. 128). To stanowisko niezwykle demokratyczne i tylko demokratyczne. Bo ten człowiek, „wolny człowiek” to — jak się zdaje, nie tylko artysta, ale i w niektórych przypadkach — człowiek prosty.

32 Ibidem.

33 Ibidem.

34 S. Baczyński, Syty Paraklet i głodny Prometeusz. Najmłodsza poezja polska, [w:] idem, Pisma krytyczne..., s. 143.

35 Ibidem, s. 150. 
Oczekiwana przez Baczyńskiego na początku lat dwudziestych rewolucja, „pogrom filisterstwa”36, miałaby więc charakter społeczny, ale przede wszystkim artystyczny, mentalny i antyfilisterski. To jest świadectwo myślenia awangardowego, demokratycznego, ale nie marksistowskiego. Uważał filistrów za ostoję mieszczańskiego gustu stanowiącego istotną przeszkodę dla pojawienia się w literaturze autentycznego, nowego języka i nowych tematów pokazujących współczesność.

\section{Umieli ją natomiast przybliżyć młodzi poeci:}

poezja nowa wyraża się promienisto, ogarnia całość życia współczesnego, nie pomijając źródeł dawnych jak przyroda i miasto, odnajduje w nich wartości nowe, symbolizujące pęd i rozległość ekspansji sił ludzkich — stwarza skojarzenia rozległe, odrębne, swoiste, istotnie twórcze. W zasadzie postawa nowej sztuki opiera się na współczynności z postępem, na uwielbieniu pracy jako motoru i konstrukcyjnej potęgi cywilizacji. Poeta dzisiejszy żyje tętnem dnia, teraźniejszością i przyszłością ${ }^{37}$.

Należy przy tym dodać, że jego poglądy cechował dość radykalny antypsychologizm - sądził, że zbytnie wgłębianie się w tajniki duszy bohatera grozi literaturze pewnym schematyzmem i stereotypowością. Nie lubił także powieści realistycznej, bo uważał, że ma ona skłonność do popadania w stereotypy, kiedy zaczyna pokazywać duchowe cechy bohatera, które są skutkiem jego społecznych nawyków.

Formułował ponadto liczne postulaty szczegółowe, których spełnienie miałoby sztuce, a raczej literaturze zapewnić skuteczność funkcjonowania w nowej rzeczywistości. Szczególnie chwalił na przykład wprowadzenie do literatury „mowy ludu miejskiego [...] gwary ulicy: dorożkarzy, posłańców, roznosicieli gazet, robotników”, gdyż ,jej plastyka oryginalna i wyrazistość jest zjawiskiem zapowiadającym język przyszłości, który wprowadzony do poezji już dziś protestuje przeciw zadżumionej sybarytyzmem duszy filisterstwa i konwencjonalnym jej frazesom"38, a „współżycie z ludem miejskim”39 uważał za istotny sukces ekspresjonizmu. Wskazywał na fatalne błędy, popadnięcie w które wyklucza wypełnienie przez poezję polską misji ważnej dla niej w nowoczesnym świecie, na przykład „wykrętne karierowiczowstwo”, „kompromis”, „wyszarzały arystokratyzm". Zwłaszcza ostatnie z wymienionych określeń świadczy o swoistym

36 S. Baczyński, Sztuka walczaca, s. 129.

37 S. Baczyński, Syty Paraklet i głodny Prometeusz, s. 156.

38 Ibidem, s. 140-141. Ciąg dalszy cytatu: ,porównywanym przez G.K. Chestertona do sznurka ze zgniłymi rybami. W poezji, zagwożdżonej wyświechtanymi komunałami, ten objaw żywotności najmłodszych zapowiadający uwspółcześnienie języka literackiego jest jurnym, impetycznym natarciem na konwenanse mowy, procesem sprzecznym z marzeniami wielbicieli piosenki pasterskiej i słowników, ale zgodnym z postulatami codziennego życia" (ibidem). Zdaje się jednak, że przywoływany Chesterton przeciwstawiał slang angielskich przedmieść i mowę ludzi prostych towarzyskiej rozmowie tak zwanych dżentelmenów, ale to tylko moje przypuszczenie.

39 Ibidem, s. 152. 
konserwatyzmie Baczyńskiego, godnym jeszcze walczących z arystokratyzmem romantycznych i pozytywistycznych demokratów w rodzaju Prusa.

\section{Gilbert Keith Chesterton}

Kiedy więc myślę o zainteresowaniach Baczyńskiego kulturą popularną, a zwłaszcza „powieścią detektywną”, widzę wyjątkowość tej myśli w całej polskiej krytyce literatury aż do przełomu lat pięćdziesiątych i sześćdziesiątych dwudziestego wieku. Przynajmniej tak się wydaje ze współczesnej perspektywy. W zasadzie w Polsce lat dwudziestych były to pasje niemożliwe. Zainteresowanie gatunkiem trywialnym? Zainteresowanie literaturą dla „niskich sfer”? Nie mieściły się takie namiętności w paradygmacie krytycznoliterackim owych i późniejszych (do połowy lat pięćdziesiątych) czasów.

To się także nie mieściło w tradycji pozytywistycznej lub modernistycznej. Romantyzm i modernistyczne chłopomaństwo w swoich pasjach ludoznawczych uwzględniały raczej folklor chłopski, a nie rozrywkową literaturę trywialną czytaną przez robotników i robotnice mieszkających na przedmieściach. Baczyński też się nią do pewnego momentu nie zajmował. Kryminał jego czasów za literaturę pełnoprawną na pewno nie był uważany i kolportowano go raczej w tanich broszurach lub magazynach w rodzaju „Co tydzień powieść”. W Europie nikt go chyba poważnie nie traktował poza niektórymi jego twórcami, jak Gilbert Keith Chesterton (1974-1936), autor felietonów przetłumaczonych przez Baczyńskiego i zebranych w tomie Obrona niedorzeczności, pokory, romansu brukowego $i$ innych rzeczy wzgardzonych (wydanym w Warszawie w wydawnictwie „Rój” w 1927 roku) ${ }^{40}$.

W oryginale, na to datowane zwykle na 1901 rok dziełko (The Defendant) składa się autorski wybór szesnastu felietonów, zapewne drukowanych pierwotnie w „The Speaker” i „The Daily News”. Chesterton - młody podówczas eseista chrześcijański - w publicystycznych tekstach: Obrona romansu brukowego, Obrona niedorzeczności, Obrona planet, Obrona farsy, Obrona pokory, Obrona nierozważnych ślubów, Obrona szkieletów, Obrona jawności, Obrona pasterek z porcelany, Obrona pożytecznej informacji ${ }^{41}$, Obrona heraldyki, Obrona rzeczy

40 Zob. przyp. 14. Wiadomości o tym myślicielu i pisarzu są ogólnie dostępne na przykład w angielskiej i polskiej Wikipedii. W polskiej literaturze przedmiotu ostatnio przypomniano jego zasługi w pracy T. Cegielski, Detektyw w krainie cudów. Powieść kryminalna i narodziny nowoczesności 1841-1941, Warszawa 2015, np. s. 30-31.

41 Dwa cytaty: „Warstwy kulturalne, przesycone i zdemoralizowane zupełnem oddaniem się sztuce i nastrojom, niezdolne są do zrozumienia próżniaczej i wspaniałej bezinteresowności niedzielnego czytelnika” (G.K. Chesterton, op. cit., s. 100); „Wiedza sama przez się jest tylko specjalizacją i przerostem tego pożądania wiadomości niepożytecznych tak znamiennego w młodzieńczym okresie człowieka. Ale wiedza wyodrębniła się w dziwny sposób od plotek i dziwnych nowin, od kwiatów i ptaków; ludzie przestali uważać, że pterodaktylos był tak samo świeży i naturalny 
brzydkich (to znaczy niezgodnych z estetycznym kanonem klasycznym), Obrona gwary, Obrona miłości do dzieci, Obrona detektywnych opowieści, Obrona patriotyzmu — dogłębnie skrytykował rozwój cywilizacji:

Dziwaczne prawo przenika odwieczne dzieje ludzkie - oto człowiek dąży usilnie do poniżenia samego siebie, swego otoczenia i jego szczęścia [...] Jest to upadek wielki, upadek, który każe zapominać rybie o morzu, wołom o łące, kupcowi o mieście - każdemu o własnem środowisku, zaś w najpełniejszym i najgłębszem znaczeniu każe zapominać o sobie ${ }^{42}$.

Rozwój cywilizacji i wysmakowanej kultury sprawił, że człowiek przestał zauważać naturalne piękno i nie odczuwa prostego szczęścia. A mógłby: „Najprawdopodobniej zaś przebywamy do tej pory w Edenie. Tylko oczy nasze się zmieniły"43.

Czyli życie nasze mogłoby być szczęśliwe, gdybyśmy tylko umieli się nim cieszyć. Chesterton zupełnie w duchu ewangelicznego podziału na „maluczkich” i „uczonych w piśmie” podzielił społeczeństwo na warstwy wyższe, kulturalne, które, ogarnięte pychą i samozadowoleniem, negują wartości oczywiste, oraz zwykłych ludzi, którzy umieją jeszcze cieszyć się światem, przyrodą i tym, co w sposób oczywisty dobre i proste — przez warstwy wyższe jest wszak ośmieszane i przedstawiane jako godne pogardy, pospolite, szkodliwe. „Światu grozi ciągłe niebezpieczeństwo fałszywego pojmowania" 44 — zaznaczał.

Do owych godnych obrony spraw prostych zaliczył na przykład poczucie sprawiedliwości i uczciwości, które nie ujawnia się w literaturze wysokiej („,iteratura najnowsza warstw oświeconych właśnie, nie niższych, stanowi czynnik zbrodniczy. We wszystkich naszych salonach leżą książki szerzące pesymizm i bezwstyd, książki, przed którymi zadrżałby wielkoduszny ulicznik" ${ }^{45}$ ), a w prostej literaturze rozrywkowej czy przygodowej ,ze zwykłych, przesadnych romansów rynsztokowych płynie zdrowszy i lepszy morał niż z błyskotliwych paradoksów etycznych, zmieniających się w świecie wytwornym tak łatwo jak moda"46.

Ponadto uznał, że w literaturze popularnej przechowało się pierwotne widzenie świata zdolne odczuć jego irracjonalność i cudowność: „Nawet najtrywialniejsze dramaty i historie kryminalne mogą być pożyteczne, gdy zawierają coś z draźniącego smaku niezwykłych możliwości, coś ze zdrowej trwogi, która ogarnia nas w nocy na pustych drogach" 47 .

jak kwiat, kwiat zaś podobnie jest potworny jak pterodaktylos. Odbudowa mostu między wiedzą a ludzką naturą stanowi jedną z największych konieczności świata. Wszyscy, zanim przejdziemy do jakichkolwiek wizyj i twórczości, musimy udowodnić, że potrafimy zadowolić się planetą pełną cudów" (ibidem, s. 102). W istocie, jak sądzę, refleksja Chestertona jest jedną z pierwszych prób wyjaśnienia popularności prasy tabloidowej, ale nie zauważyłem, by była znana jej polskim znawcom.

42 Ibidem, s. 11.

43 Ibidem.

44 Ibidem, s. 12.

45 Ibidem, s. 22.

46 Ibidem, s. 23.

47 Ibidem, s. 29. 
Jeśli zaś chodzi o „powieść detektywną”, postawił na jej temat konkretne tezy:

1. O posiadaniu przez kryminały walorów estetycznych („,dobra historia kryminalna byłaby prawdopodobnie bardziej popularna niż zła"48), których jednak czytelnicy z warstw wyższych nie dostrzegają wskutek ulegania sile stereotypu.

2. O ich swoistości - „istotna, zasadnicza wartość opowiadań detektywnych tkwi w fakcie, że stanowią one najwcześniejszy i jedyny przejaw literatury popularnej, w którym zaznacza się zmysł do odczuwania poezji współczesnego życia [...] w obliczu wielkiego miasta, jako czegoś niebezpiecznego i godnego podziwu jest historia detektywna Iliadą"49.

3. O jej zdolności do pokazania estetycznych walorów współczesnego miasta (,miasto jest fantastyczniejsze niż wieś” ${ }^{50}$, „ponieważ jednak wielcy pisarze nasi [...] nie chcą opisywać tego niesamowitego nastroju, który rodzi się w nas, gdy oczy wielkiego miasta zaczynają płonąć w ciemnościach, niby kocie źrenice, należy zaliczyć to wyłącznie na dobro literatury popularnej, która wśród gderliwej pedanterii i przesady nie chce spoglądać na teraźniejszość jak na sprawę prozaiczną, a uważać codzienność za pospolitość" ${ }^{51}$ ).

4. O jej zdolności do stania się miejskim odpowiednikiem ludowego folkloru (,Z romantycznych możliwości nowoczesnego miasta musiała powstać nieuładzona literatura ludowa, wyłoniła się ona w detektywnych opowiadaniach tak pierwotna i odświeżająca, jak ballady Robin Hood'a"52).

5. O kontynuacji tradycji romansu (i etosu) rycerskiego w postaciach policjantów $^{53}$.

Baczyński - czemu dał wyraz we wstępie do swego przekładu — przeczytał Chestertona okiem starego demokraty, bezbłędnie odczytując odpowiednie ewangeliczne nawiązania („Błogosławieni poniżeni...”54), dostrzegając - jako ekspresjonista - przeciwstawianie przez Chestertona poczucia estetycznego swoistego dla osobowości prostych i ,duszy, która ugięła kolana przed bałwanem tej cywilizacji, przed konwenansem" ${ }^{55}$, krytykując współczesną inteligencję, która „zapomniała o wzniosłości” i „silnych wzruszeniach” ${ }^{56}$. Uznał na koniec, patrząc okiem zwolennika awangardy, że Chesterton dąży do ,szukania poezji nowoczesnej w duszy thumu”57, że jego książka jest „manifestem przyszłości raczej niż

48 G.K. Chesterton, Obrona detektywnych powieści, [w:] idem, Obrona niedorzeczności..., s. 137.

49 Ibidem, s. 138.

50 Ibidem, s. 139.

51 Ibidem, s. 140.

52 Ibidem, s. 141.

53 Ibidem.

54 S. Baczyński, Przedmowa tlumacza, [w:] G.K. Chesterton, Obrona niedorzeczności..., s. III.

55 Ibidem, s. II.

56 Ibidem.

57 Ibidem, s. IV. 
literacko-adwokackim roztrząsaniem kontrastów współczesnego życia"58, że jest on ,poetą, jednym z nielicznych, którym objawiła się prawda życia, nie w sferze złudzeń, ale w rzeczywistości codziennej, w wiekuistym ruchu wyobraźni najnędzniejszych, nawet pariasów ludzkich, w oceanie i przydrożnej kałuży"59.

Ponieważ i jako inteligent swoich czasów, i jako uczeń Brzozowskiego, i jako nauczyciel gimnazjalny przyzwyczajony był do szukania poznawczych i estetycznych sukcesów literatury w dziełach najdoskonalszych, musiał go bardzo zdziwić poważny stosunek Chestertona do literatury trywialnej. Jak sądzę, Powieść kryminalna musiała się zrodzić z zaintrygowania, z chęci sprawdzenia, czy angielski pisarz może mieć rację.

\section{Powieść kryminalna}

Jako dziecko swoich czasów, uczeń Brzozowskiego i Nietzschego, skłonny był Baczyński do tworzenia społecznych i filozoficznych konstrukcji obejmujących całe epoki rozwoju ludzkiej kultury. Krytyk więc w charakterystyczny sposób zabrał się do weryfikacji myśli Chestertona. Powieść kryminalna w zasadzie składa się z dwóch wątków: rozważań o społecznej charakterystyce zbrodni i rozważań o opowieści pokazującej zbrodnię, przy czym krytyk zakładał, że formy literackie o niej traktujące dostosowane są do obowiązujących w danej epoce sposobów myślenia o niej.

Deklarował podejście tolerancyjne i antynormatywne polegające na wyznaczeniu romansowi kryminalnemu miejsca w literaturze, a nie na ogłoszeniu „sądu moralnego o jego wartości pedagogicznej, obronie lub oskarżeniu" ${ }^{60}$. Deklarował „wyznaczenie mu właściwego w literaturze miejsca”61, występując przeciw „wypomadowanym elegantom spoglądającym z fałszywą pogardą na fermenty życia "nizinne « i estetom pełnym konwencjonalnych morałów, zżartym wewnętrznie przez robactwo utartych formułek" ${ }^{\prime}$, czyli zgodnie z duchem demokratycznym, antymieszczańskim, antyarystokratycznym.

Pierwszy rozdział Krew na Parnasie przynosi podstawowe definicje i omówienie koncepcji istotnych w literaturze wysokiej. Zbrodnia, zawsze definiowana jako „wykroczenie przeciw prawu gromady"63, ma wedle Baczyńskiego trzy aspekty: religijny, społeczny, moralny, które po kolei wychodzą na plan pierwszy w różnych epokach; ponadto, choć zbrodnia $\mathrm{z}$ reguły jest odpychająca, dokonujący jej zbrodniarz może budzić współczucie, a nawet stać się pozytywnym bohate-

\footnotetext{
58 Ibidem.

59 Ibidem.

60 S. Baczyński, Powieść kryminalna, Kraków-Warszawa 1932, s. 6.

61 Ibidem.

${ }^{62}$ Ibidem, s. 7.

63 Ibidem, s. 11.
} 
rem, jeśli prawo, które łamie, uważane jest za niesprawiedliwe w danej sytuacji. W starożytnej tragedii zbrodniarz walczył z bogami i ludźmi, bywał usprawiedliwiany w dziełach poetyckich $\mathrm{z}$ występku wobec prawa boskiego i społecznego, jeśli postępował zgodnie z uczuciami i sumieniem (jak Antygona). Nie mógł być człowiekiem słabym. Zbrodnia jest motywem wysokim, arystokratycznym — wybitna, potężna jednostka walczy z Przeznaczeniem, a widz, współczując pokonanemu zbrodniarzowi, odczuwa katharsis.

W epoce nowożytnej religijny i kosmiczny sens ginie, tragedia przeistacza się w dramat, zbrodnia pozostaje postępkiem społecznym (i zbrodniarz, jeśli prawo jest niesprawiedliwe, może znaleźć obrońców). Natomiast tylko zbrodniarzem i tylko nim jest człowiek niemoralny. Chrześcijaństwo toleruje zbrodnię jako słabość, ale jej nie wywyższa. U Szekspira zbrodniarze są tylko czarnymi charakterami. Nie budzą współczucia, nie ma więc katharsis. Zbrodnie wynikają ze słabości i nędzy moralnej, to negatywny przywilej dworski.

Pojawia się jednak w czasach feudalnych zbrodniarz ludowy bohater, gdyż prawo nie traktuje jednakowo wszystkich członków społeczeństwa, więc zbrodnia w ujęciu ludowym (w pieśni) staje się bohaterstwem i protestem społecznym, prawna kara wymierzona przestępcy — krzywdą, prawdziwymi zbrodniarzami - sądzący (na przykład Janosika).

Z końcem XVIII wieku, z początkiem romantyzmu następuje koniec zarówno klasycznej, jak i szekspirowskiej (dworskiej) koncepcji zbrodni uprzywilejowanej. Zbrodnia przestaje być rozumiana głównie jako złamanie prawa, staje się skrzywdzeniem innego człowieka. Rozumienie zbrodni w literaturze nabiera charakteru moralnego ${ }^{64}$, jak w Zbójcach Friedricha Schillera. Ponieważ prawem i racją usprawiedliwiającą postępek staje się uczucie, literatura zaczyna traktować oficjalnych sędziów i oskarżycieli jako zbrodniarzy, niejako staje po stronie ludowego spojrzenia na prawo. Natomiast zbrodniarz staje się w romantycznych realizacjach bądź konsekwentnym „czarnym charakterem” (jeśli, jak w schematach walterscottowskich i innych przygodowych, pojawia się schematyczny podział na „dobrych i złych” bohaterów), bądź występuje bohater niejednoznaczny, o dobrych i złych cechach, co doprowadza do rozwoju powieści psychologicznej, której Baczyński nie lubi, gdyż w niej „sprawa dobra i zła przestaje być kwestią realnego układu w człowieku żywym, zaczyna się zmieniać w problemat czysto literacki, nierealny, zmyślony, zależny w swym rozwiązaniu od tezy czy postawy autora" ${ }^{65}$. Złe i dobre pierwiastki, cechy sprzeczne łączą się w bohaterze w jedno, co stanowi ,zaród tragizmu oparty na wewnętrznych sprzecznościach"66. Tym

${ }^{64}$ Por. „Nie człowiek przekraczający prawo jest zbrodniarzem istotnym, ale wszelki czynnik przemocy i siły, gwałcący słabość i krzywdzący bliźniego już to dzięki swym przywilejom bezkarności, już to inteligencji czy sile fizycznej” (ibidem, s. 23).

65 Ibidem, s. 27; taką „powieścią z tezą” była dla niego Zbrodnia i kara Fiodora Dostojewskiego — według Baczyńskiego Raskolnikow jest punktem dojścia ewolucji postaci zbrodniarza w europejskiej dziewiętnastowiecznej, wielkiej powieści.

66 S. Baczyński, Powieść kryminalna, s. 26. 
sposobem opowieść o zbrodni przestaje mieć też charakter dydaktyczny i „motyw zbrodni w literaturze [...] przechodzi w fazę czysto literacką "poza dobrem i złem«. Tak przynajmniej pojmowała go literatura »dekadencka« z końca XIX i początków XX wieku"67.

Właściwa powieść kryminalna zrodziła się — zdaniem Baczyńskiego — wraz ze współczesną cywilizacją i organizacją pracy, a przede wszystkim policją, w połowie XIX wieku. Zaspokajała:

— potrzebę współczesnego czytelnikom, a nie historycznego, romantycznego heroizmu: „smak [...] zagadki leży nie tylko w akcji, ale i w traktowaniu jej na jednej linii z życiem czytelnika, na złudzeniu, że przeżywamy ją i rozwiązujemy, jakby to była sprawa naszego osobistego życia. »Jutro« $\mathrm{i} »$ wczoraj« muszą być w powieści »jutrem« $\mathrm{i} »$ wczoraj« czytelnika" ${ }^{68}$. Baczyński uważa, że współczesny czytelnik jest zwrócony ku swojemu dniu dzisiejszemu, powszedniemu i chciałby w nim przeżywać przygodę, w tym przygodę heroiczną. „Literatura popularna”, „romans ludowy”, „sprowadzony do tematyki kryminalnej”"69 zaspokaja to marzenie;

- potrzebę poczucia społecznego bezpieczeństwa, gdyż „wprowadziła do literatury te czynniki praworządności i porządku społecznego, których znaczenie wzrosło niepomiernie w czasach demokracji”70. Baczyński ma na myśli policję ${ }^{71}$. Prawo i policja zyskały ,znaczenie czynnika nawet pierwszorzędnego w kompozycji literackiej, wypełniającego doskonale rolę dramatyczną w stosunku do zbrodni" 72 . W ten sposób schemat fabularny zaczął oddawać stosunki w państwie demokratycznym.

- potrzebę pokazania w utworze fabularnym współczesnego sposobu myślenia skupionego na życiowych konkretach, a nie na kontemplacji pojęć abstrakcyjnych:

usunięcie walki wewnętrznej i sprowadzenie wątku zdarzeń tylko do dwu sił: zbrodniarza i policji wyniosło powieść popularną z zakamarków psychologicznych na powierzchnię życia, kazało jej, zamiast kontemplować — działać dramatycznie, zamiast analizować fikcyjne stany duchowe bohaterów - kojarzyć fakty zewnętrzne, zamiast poematu tworzyło krzyżówkę, równanie z niewiadomą i rebus logiczny. Romans kryminalny stał się w ten sposób jednym z przejawów ekspansywnego życia nowoczesnego, w którym zagadką są fakty, nie zaś tezy abstrakcyjne ${ }^{73}$.

\footnotetext{
67 Ibidem, s. 27.

68 Ibidem, s. 35.

69 Ibidem.

70 Ibidem, s. 38.
}

71 „Autorytet prawa zyskał w literaturze swe pełne walory oficjalne i zaczął występować w galowym i służbowym mundurze [...]. Było to jednoznaczne z wprowadzeniem do literatury tych czynników praworządności i porządku społecznego, których znaczenie wzrosło niepomiernie w czasach demokracji. Jedną zaś z głównych agend była policja. [...] Taki Javert z Nędzarzy Hugo lub Porfiriusz Piotrowicz ze Zbrodni i kary Dostojewskiego byli nieledwie słabą zapowiedzią współczesnej policji i jej władzy nad czynami i sumieniem obywateli państwa demokratycznego" (ibidem).

72 Ibidem, s. 39.
73 Ibidem. 
Baczyński rozumuje więc jak awangardzista: antypsychologiczna konstrukcja bohatera, narracja nastawiona na relacjonowanie wydarzeń, a nie refleksje psychologiczne i opisy, prosty porządek w świecie przedstawionym i możliwy do jednoznacznej oceny konflikt fabularny to kategorie, które umożliwiają przedstawienie życia takiego, jakim powinien je widzieć współczesny obywatel żyjący w świecie nowoczesnego rozwoju i kapitalistycznej demokracji. Zapoznawanie się ze światem popularnych kryminalnych powieści ułatwia więc życie w warunkach współczesnej miejskiej cywilizacji w nowoczesnych demokratycznych państwach.

I na tym polega główna rola popularnych powieści, a przede wszystkim kryminału. Literatura popularna, ze względu na cechy kompozycyjne, wdraża do współczesnego życia. Przynajmniej teoretycznie powinna. Dalsze rozdziały będą pokazywać, na ile w praktyce w literaturze poszczególnych krajów spełnia się ta możliwość i jeszcze inne.

Póki co jednak, w rozdziale IV (Romans kryminalny) krytyk zajmuje się kwestiami konstrukcyjnymi. Tak zwany schemat fabularny kryminału nie ma charakteru „szablonu dedukcyjnego" 74 jak powieść tendencyjna prezentująca „rzeczywistość na miarę wymysłu" ${ }^{\text {"7 }}$ (w rodzaju — zdaniem Baczyńskiego — Zbrodni $i$ kary Dostojewskiego),

obojętne jest tutaj powikłanie i konflikty psychologiczne bohaterów, interesująca jest tylko walka zbrodni z prawem lub na odwrót [...] Przeciętny romans kryminalny jest równaniem matematycznem. Dana jest zbrodnia i prawo, zagadnienie stanowi zbrodniarz: przyczyna dramatu ${ }^{76}$.

Budowę fabuły, u źródeł której kryje się zbrodnia, sprawcę której i przyczyny należy indukcyjnie bądź dedukcyjnie ustalić, opisuje Baczyński w słowach niezbyt prostych dla dzisiejszego czytelnika, o ile nie jest on obeznany z dawną terminologią logiczną. Jego słowa brzmią następująco:

Cel jest jeden: zbrodniarz w postaci znaku zapytania. „Kto winien?” [...] W pytaniu tem streszcza się całe zagadnienie romansu kryminalnego. Aby je rozwiązać, autor musi skłonić czytelnika do śledzenia wszystkich szczegółów akcji, prowadzącej do niewiadomego X. Mając z góry zaplanowane rozwiązanie, autor musi je rozłożyć na szereg stopni logicznych, zależnych od stwierdzanych kolejno szczegółów zbrodni, musi niepokoić wyobraźnię, ukazywać jej manowce i labirynt, z którego wreszcie ukazuje się jedno logiczne, pełne równanie. Ta gra między logiką a fantazją stanowi największy czynnik atrakcyjny kryminalnej powieści ${ }^{77}$.

74 Ibidem, s. 43.

75 Ibidem.

76 Ibidem, s. 44-45.

77 Ibidem, s. 45. I dalej: „Od zachowania równowagi między powieścią a logiką czytelnika zależy wynik jego domysłów i wniosków. Jeżeli podda się fantazji, zapomniawszy o logice, popełni błąd i pomyli się, jeżeli postąpi odwrotnie, popełni również błąd. W tego typu literaturze bowiem musi kierować kompozycją logika wyobraźni. [...] W przeciwieństwie bowiem do powieści obyczajowej, historycznej, powieści z tezą i problemem romans kryminalny nie szuka prawdopodobieństwa, ale fikcji umotywowanej logicznie. Nie absorbuje ani grą psychologiczną, ani problemem moralnym, nie ma pretensyj do odtworzenia rzeczywistości, lecz buduje sobie tę rzeczywistość chimerycznie, z elementów życia układa na zasadach ścisłego myślenia nową rzeczywistość. Wobec 
Właściwym twórcą kryminału jest przy tym — zdaniem Baczyńskiego — Conan Doyle, w którego nowelach i powieściach

wypadki i ludzie [...] układały się posłusznie dookoła pomysłów genjalnego detektywa, wyłączając przez swą zawartość wszelką konwencjonalną ornamentykę powieściową, jak liryzm, malarstwo opisowe i psychologiczną analizę, na powierzchni pozostawała tylko naga tkanka faktów, myśli i działań detektywa, napięta między zbrodnią a odkryciem jej sprawcy. Dopiero na marginesie, po zdemaskowaniu zbrodniarza było miejsce na resztki konwenansu literackiego, w postaci dygresyj humanitarno-lirycznych ${ }^{78}$.

Ponieważ rozdział kończy się optymistycznym stwierdzeniem, że oto kryminał dzięki Arthurowi Conan Doyle’owi stał się „nawet wyrazem życia społecznego współczesnej Anglii i daje doskonały materiał do przekroju świadomości przeciętnego obywatela" ${ }^{79}$, wydaje się, że Baczyński był dobrego zdania o tych „przeciętnych obywatelach”, prostych Anglikach, skoro przypisywał im tak dużą logiczność i konkretność myślenia, że właśnie reprezentujący te jakości gatunek miał trafić im do przekonania.

\section{Kryminały w poszczególnych krajach}

W następnych rozdziałach książki Baczyński analizuje współczesne romanse kryminalne w kolejnych literaturach Zachodu, czyniąc uwagi o tym, co konstrukcja powieści kryminalnych w ich ramach pisanych mówi o stanie społeczeństw i mentalności przeciętnych czytelników w danym kraju.

Zaczyna od kryminału angielskiego, który jego zdaniem jest najlepiej rozwinięty, powstał bowiem w kraju o najdłuższych, współczesnych tradycjach demokratycznych i o obywatelach wychowywanych w poszanowaniu dla prawa. Motorem działania postaci pozytywnych jest albo państwotwórczy heroizm policyjny, albo pozostałość po romantyzmie — starania wybitnej jednostki — detektywa-amatora mogącego być jednocześnie nie tylko wybitnym indywidualistą

tego i układ faktów w nim się różni od konwenansu literatury artystycznej. Ma on własny szablon. Katastrofa dramatyczna jest w nim już na początku dokonana (zbrodnia), albo od niej akcja się rozpoczyna. Punkt szczytowy akcji nie wynika z ugruntowania faktów, lecz z pracy wyobraźni i myśli, usiłujących odbudować ekspozycję dramatu za pomocą poszlak, domysłów i logiki. Nie fakty są tu ważne, ale właśnie ów rachunek, usiłujący z dokonanej tragedii odtworzyć jej stadja poprzedzające, wyjaśniające jej motywy i szczegóły. W tym sensie można dopatrywać się w romansach kryminalnych motywów społecznych, obyczajowych i historycznych, zależnie od wątku ich treści. Kierownikiem zaś całej pracy jest tu nie charakter, typ [to jest według Baczyńskiego stereotyp mieszczański czy inny - W.K.], lecz symbol logiki — mózg, przybrany w konwencjonalny strój: detektywa, inspektora policji [...]. Słowem, jak powiedziano, punktem szeregującym wypadki i ludzi w romansie kryminalnym jest wyobraźnia i myśl człowieka, który przychodzi z zewnątrz, wdziera się w te wypadki z całym obiektywizmem i układa je według logiki swej fantazji. I taki człowiek jest właściwym bohaterem akcji kryminalnej, jej »typem« literackim” (ibidem, s. 45-47).

78 Ibidem, s. 47-48.

79 Ibidem, s. 48. 
jak Sherlock Holmes, lecz także przeciętnym amatorem jak ksiądz Brown Chestertona ${ }^{80}$. Ponadto gatunek zaspokaja, będące psychiczną powojenną pozostałością, nieświadome pragnienie „sadyzmu”. Chodzi o „sadyzm prawny, społeczny i indywidualny, który szuka rozkoszy w fikcji literackiej"81. Opisy zbrodni budzą potrzebę zemsty (czytelnik utożsamia się z obrońcami ładu społecznego), którą z kolei zaspokaja złapanie i ukaranie przestępcy.

Gatunek jest więc reakcją na jakieś podskórne pragnienie kontaktu ze złem obecne w czytelnikach, daje efekt katarktyczny, podobnie jak prasa brukowa (dzisiejsze tabloidy). Tym sposobem zaspokaja ważną społeczno-psychologiczną potrzebę i staje się (swoistą, ale jednak) odpowiedzią na nadejście „nowych czasów" potrzebujących nowej literatury. Niestety, wskutek mało wymyślnego zaspokajania rosnącego popytu grozi mu degeneracja, szukanie ostrych efektów może sprawić, że „kult prawa łatwo się przeistoczy w kult zbrodni”82, a ponadto w dążeniu do coraz to większej czytelniczej atrakcyjności traci gatunkową czystość, pojawia się domieszka romansowa, wątki erotyczne.

Kryminał francuski tym się różni od angielskiego, że respektuje „heroizm galicyjski”, który rodzi się z „walki z regułami i prawem, z przeciwstawienia się indywidualności gromadzie, a oryginalnej jednostki przeciętnemu ogółowi"83. Z sympatią odnosi się do zbrodni z namiętności, jest pełny fantazji, humoru, pojawia się w nim sylwetka zbrodniarza-bohatera (Arsen Lupin), a o wartości człowieka decyduje w nim ,nie [...] sąd prawa i władzy oficjalnej, lecz spryt i inteligencja” ${ }^{4}$. Baczyński uważa, że taka koncepcja jest „odwiecznym przejawem legendy o duszy galicyjskiej i personifikacją jej poglądu na świat" ${ }^{\prime 5}$. Francuski detektyw zaś nie jest logikiem, jego „awantury [...] są fantazją romantyczną, przełamującą powszedniość, ucieleśnieniem marzeń i pragnień gorącej krwi" ${ }^{86}$.

Baczyński sądzi, że co prawda nie mamy tu do czynienia z efektem katarktycznym, lecz jednak nadal z głębszym sensem społecznopsychologicznym:

legenda $[\ldots]$ o wielkim detektywie i genialnym zbrodniarzu ma znaczenia poważniejsze niż pospolicie sądzimy, jest ona marzeniem o nowym człowieku, dla którego prawo będzie religią opartą o najistotniejsze popędy i potrzeby natury ludzkiej, religią, wynikającą z poczucia odpowiedzialności i wysokiej kultury moralnej, nie zaś martwego paragrafu i ślepego odwetu. Dopiero wychowanie człowieka w prawie i dla prawa niweczy całą dialektykę zbrodni i romantyzm zbrodniczy. Na tej drodze romans kryminalny zdziera powoli z oczu Temidy przepaskę i każe jej patrzeć prawdzie w twarz ${ }^{87}$.

\footnotetext{
80 Por. ibidem, s. 55.

81 Ibidem, s. 53.

82 Ibidem, s. 58.

83 Ibidem, s. 63.

84 Ibidem, s. 66.

85 Ibidem, s. 67.

86 Ibidem.

87 Ibidem, s. 68.
} 
Wywód ten jest dość ciekawy, gdyż stanowi przejście od naturalnego w czasach Baczyńskiego myślenia o cechach narodowej literatury jako o funkcjach narodowego charakteru ku konstruktywistycznej, awangardowej koncepcji literatury rozumianej jako szczególny środek wychowujący społeczeństwo, na przykład poprzez ukazywanie mu jego „ucieleśnionych marzeń”. Niestety dalej Baczyński nie rozwinął tej koncepcji w omawianej książce.

Porównując angielski i francuski kryminał, Baczyński uważa ten drugi za bardziej artystyczny, a właściwie — co w tym wypadku jest zaletą — i psychologiczny, i artystyczny ${ }^{88}$. Światopoglądowe różnice między nimi znalazły też odpowiedniki formalne w ich kompozycji — związane z możliwościami dramatycznymi, budową postaci i konstrukcją fabuly:

Powieść kryminalna francuska [...] zachowując tradycje romantyczne, utrzymała paradoksalny punkt wyjścia w oxymoronie, rozszczepia człowieka stale na dwie sprzeczne chociaż równoległe pierwiastki: na dobro i zło. Policja i prawo stanowi w tym wypadku element dopiero trzeci z rzędu, co zwiększa możliwości dramatyczne. Angielski zaś romans tkwi nadal w dualiźmie charakterów czarnych i białych, skrzepniętych w wyłączających się nawzajem postaciach zbrodniarzy i reprezentantów prawa ${ }^{89}$.

W Niemczech, gdzie prawo odbiera się jak fatum i pisze raczej powieści realistyczne z wątkiem kryminalnym, nie ma jak dotąd rozwiniętej literatury kryminalnej. Podobnie w literaturze skandynawskiej. Ferujący takie wyroki i charakterystycznie zatytułowany (Zbrodniarz bez patosu) rozdział zawiera za to klasyfikację powieści kryminalnej na trzy grupy:

1. powieść brukową - naiwną w treści, nędzną w formie, o jakości „wymykającej się wszelkim sprawdzianom krytycznym"90 — lichą, spekulacyjną, amatorską, drukowaną tylko z racji istnienia popytu na nią;

2. powieść „o motywach wybitnie kryminalnych, lecz należącą do wysokogatunkowej literatury artystycznej"91, przede wszystkim po prostu realistyczną, z analizą psychologiczną i społeczną na standardowym poziomie. „Zagadnieniem nie jest tu pytanie: »Kto winien?«, lecz »Dlaczego winien?«"92. Ta różnica „przenosi motyw zbrodni ze sfery śledztwa w sferę zagadnień socjalnych i moralnych" 93 i jest różnicą między romansem kryminalnym a realistyczną powieścią o wątku kryminalnym;

3. tak zwane poprawne romanse kryminalne typu angielskiego czy francuskiego (czyli detektywistyczne lub „czarne kryminały”, jeśli użyć współczesnego nazewnictwa).

88 „Pod względem typizacji i szablonu powieść angielska osiągnęła rekord, poszła po linii najsłabszego oporu i utrzymała swój charakter brukowej sensacji, gdy francuska zbliżyła się do literatury artystycznej" (ibidem, s. 69).
89 Ibidem, s. 68.
90 Ibidem, s. 73.
91 Ibidem, s. 74.
92 Ibidem, s. 75.
93 Ibidem. 
Niemiecka powieść kryminalna jest „dramatem o napięciu erotycznem, towarzyskiem, społecznem, lecz nie policyjnem. Ma on, słowem, pewien patos prawdziwego życia i realizm"94, a analiza psychologiczna bohaterów wskazuje na „brak [...] silnych motywów walki wewnętrznej, literackiego rozszczepienia duszy na pierwiastki zła i dobra w jednej postaci, czy też uosobienia tych pierwiastków w charakterach czarnych i białych" 95 .

Omawiane utwory skandynawskie uznaje Baczyński za typowe „romanse awanturnicze, fantazje poza czasem i przestrzenią, literaturę zabawną i bezpretensjonalną, ale też bez głębszego znaczenia" 96 .

W krajach słowiańskich — twierdził Baczyński, nie podając źródła danych — a dokładniej w Rosji i Polsce „czysto kryminalne powieści rosyjskie i polskie nie stanowią nawet $1 \%$ wobec ogólnej produkcji zachodnio-europejskiej" $" 97$. W Rosji, mimo że temat zbrodni w literaturze jest bardzo częsty i ma wspaniałą tradycję Dostojewskiego, kryminał praktycznie nie istnieje, bo nie było i nie ma demokracji, a ,do powstania prawdziwego romansu kryminalnego nie tylko potrzebny jest zbrodniarz i detektyw, ale kultura prawa w społeczeństwie i szacunek dla wykonawców woli zbiorowej" 98 , które tylko w demokracji mogą się rozwinąć.

Polska powieść kryminalna (za wyjątkiem paru ambitniejszych pozycji Leo Balmonta i Antoniego Marczyńskiego) także — zdaniem Baczyńskiego — nie istnieje i nie zaistnieje „dopóki nie pojawi się na wschodzie Europy pełne uzgodnienie i ówspółcześnienie pojęcia obywatela, prawa i państwa. Wówczas dopiero będzie możliwa i u nas literatura kryminalna w dobrym stylu" "99. Literatura polska bowiem ma charakter wysoce arystokratyczny i szlachecki: „nie wyzbyła się jeszcze swych tradycji pańskich, gdyż układy jej myślowe, pojęcia i wyobrażenia obce są do dziś masom, a szczególnie tam, gdzie idzie o stosunek do władzy i prawa"100.

Na razie nie może się rozwinąć powieść kryminalna w kraju, w którym demokracja zaczęła się rozwijać dopiero od 1918 roku — sądzi Baczyński i przytacza na to dowody:

— szczególny stosunek do policji będący mieszaniną „dydaktyzmu policyjnego, gloryfikacji wprost stójkowych" ${ }^{101}$ z głęboką do niej pogardą: policjant „to przeważnie prosty szpicel, »łapacz« równej inteligencji ze złodziejem"102, niezgodny ze standardami demokratycznego państwa;

\footnotetext{
94 Ibidem, s. 79.

95 Ibidem.

96 Ibidem, s. 82.

97 Ibidem, s. 86.

98 Ibidem, s. 90.

99 Ibidem, s. 94.

100 Ibidem.

101 Ibidem, s. 95.

102 Ibidem, s. 96.
} 
— traktowanie zbrodni jako wytworu społecznych „dołów”: „Z góry szuka się źródeł występku tylko w mętach wielkomiejskich"103;

- ignorowanie możliwości wystąpienia zbrodni w kręgu społecznych elit: „romans kryminalny polski każe wierzyć, iż zbrodnia płynie wyłącznie z nizin, wylęga się w rynsztokach, a policja działa tylko w tych sferach"104.

Ta teza polskiej kryminalnej powieści oddala nas od Zachodu ${ }^{105}$, jest nieprawdziwa (tu Baczyński wymienia znane skandale związane z członkami elit, łącznie ze zbrodnią ojca Macocha ${ }^{106}$ — co mogło nader zdenerwować ewentualnego polskiego prawicowego katolickiego czytelnika), a przede wszystkim nie pokazuje równości wobec prawa i władzy, która „przedstawiona w romansie, sprzyja demokratyzacji pojęć"107.

W tym miejscu Baczyński, prowadzący dotąd dość tradycyjną analizę społeczną, na koniec zdradza konstruktywistyczny, awangardowy rys swojego myślenia. Wskazuje wprost na możliwość wpływu romansu o tak, a nie inaczej skonstruowanym bohaterze na poglądy i nastroje społeczne. Negatywny bohater kryminału, będący nie tylko zbrodniarzem, ale i członkiem niskiej grupy społecznej, stanowiący więc postać socjologicznie dla niej typową, nie uruchamia w czytelniku myślenia demokratycznego, akcentującego równość ludzi wobec prawa. Wygląda jednak na to, że jeśli położy się nacisk na możliwość pojawienia się cech zbrodniczych u członków wyższych sfer społecznych, to będzie ona cechą uniwersalną, a im więcej się takich postaci stworzy w ramach jakiegoś gatunku, tym bardziej lektura utworów w tym gatunku będzie budzić u czytelnika poczucie demokratycznej równości, a nie wyobcowania. Pomoże mu więc dostosować się do nowej rzeczywistości, coraz to mniej klasowej, a bardziej demokratycznej.

Drugim charakterystycznym elementem uzasadniającym popularność kryminalnego romansu jest dla Baczyńskiego jego funkcja katarktyczna rozumiana już nie jako konieczność lat po pierwszej wojnie światowej, ale jako cecha bardziej uniwersalna:

Ze stanowiska względnej teorii zbrodni ${ }^{108}$ literatura kryminalna ma duże warunki rozwoju. Będzie ona istniała tak długo, niezależnie od postaci, jak długo namiętności ludzkie nie zostaną

103 Ibidem.

104 Ibidem, s. 97.

105 „Romans kryminalny francuski czy angielski ukazuje czytelnikom prawdę, iż zbrodnia jest zjawiskiem właściwem wszystkim warstwom, nie ogranicza przestępstwa tylko do zaułków miejskich" (ibidem).

106 Wymienienie tego imienia — jasnogórskiego zakonnika, kochanka, mordercy i złodzieja, na pewno nie jest przypadkowe. W swoim czasie szeroko znana sprawa, przez lata musiała być nie lada kłopotem dla kręgów polskiej, katolickiej prawicy. Niedawno w sieci opublikowano dokument z epoki, broszurę: „Proces księdza Damazego Macocha w Piotrkowie o zabicie brata w klasztorze na Jasnej Górze i o kradzież pieniędzy kościelnych. W dniach od 27-29 lutego i od 1-9 marca 1912" (https:// polona.pl/item/proces-ksiedza-damazego-macocha-w-piotrkowie-o-zabicie-brata-w-klasztorze-na-jasnej-gorze,MzIwNjk1MzQ/4/\#item, dostęp: 17.11.2018).

107 S. Baczyński, Powieść kryminalna, s. 87.

108 Przedostatni, XXI rozdział Powieści kryminalnej pod tytułem Filozofia romansu kryminalnego wskazuje, że mamy w romansie kryminalnym dążność do sformułowania swoistej filozofii 
unormowane albo przez zmechanizowaną etykę organizacyjną, albo przez absolutnie wyzwoloną, indywidualną odpowiedzialność człowieka wobec własnego sumienia. Dopóki ludzkość nie osiągnie stopnia rozwoju pewnych gatunków zwierząt, które się wzajemnie nie pożerają, dopóty będzie istniało pojęcie zbrodni i kary. A ponieważ jest to absurd w samem założeniu — zbrodnia i literatura o niej mają jeszcze wielki etap do przebycia. Będą długo zaspokajały głód wyobraźni i „sadyzm” obywateli, dając łatwe ujście ich żądzom i namiętnościom, które inaczej mogłyby postawić ich przed kratami sądu i więzienia. W tem znaczeniu bowiem literatura kryminalna stanowi doskonały środek odciągający nadmiar krwi, lekarstwo spreparowane przez zbiorowość dla zniweczenia czynnej energii popędów i nieświadomych dążności natury ludzkiej. Wydobywa ona całe złoża psychicznych fermentów i kompleksów, wyczerpuje je i spycha w nicość. Czytana przez zawodowych opryszków, daje im niewątpliwie materiał i wyższe, chociaż dyletanckie poczucie smaku zbrodni; to samo jednak zadanie spełnia w rękach policjantów. Ale dla reszty społeczeństwa jest tylko lekarstwem i, co więcej, rozrywką ${ }^{109}$.

$$
* * *
$$

Powieść kryminalna Stanisława Baczyńskiego jest dziś przede wszystkim szacownym zabytkiem, niemniej opartym na zdrowych fundamentach. Liczy się sam pomysł podjęcia refleksji nad gatunkiem popularnym i poszukania genezy jego przemian w społecznym rozwoju. Potwierdziła się też myśl o związku między rozwojem państwa demokratycznego i kryminalnej powieści, chyba żeby zachować sceptycyzm i stwierdzić, że o ostatnim bujnym rozwoju tego gatunku w Polsce zdecydowała nie tyle zmiana ustrojowa, ile fakt, że w rezultacie tej zmiany kraj stał się bogatszy i mniej policyjny, a skoro bardziej sensowne i łatwiejsze stają się przestępstwa, to gatunek je opisujący zyskuje na realizmie i popularności.

\section{Bibliografia}

\section{Teksty}

Baczyński S., Literatura w Z.S.R.R., Wydawnictwo Literacko-Naukowe, Kraków-Warszawa 1932. Baczyński S., Losy romansu, Towarzystwo Wydawnicze „Rój”, Warszawa 1927.

Baczyński S., Pisma krytyczne: Wyboru dokonat i wstępem poprzedzit Andrzej Kijowski, Państwowy Instytut Wydawniczy, Warszawa 1963.

Baczyński S., Powieść kryminalna, Wydawnictwo Literacko-Naukowe, Kraków-Warszawa 1932.

\footnotetext{
zbrodni. Ogólnie rzecz biorąc, Baczyński jest zdania, że zbrodnia może być: 1. obiektywna „społecznie niezainteresowana, ujmująca zbrodnię jako element kosmiczny i nie do zastosowania w romansie kryminalnym (tak ujęty motyw istnieje w literaturze wyższej, w odmianie pogańskiej lub chrześcijańskiej)" (ibidem, s. 101); 2. subiektywna, ujmowana a) „ze stanowiska zbrodniarza" (ibidem), to jest relatywistyczna, uzależniająca prawo do zbrodni od zdolności przestępcy, b) ,ze stanowiska narzędzia prawa, detektywa i policji” (ibidem). Ostatni, krótki rozdział książki Baczyńskiego - Prasa brukowa (ibidem, s. 110-113), wskazuje, że i ten rodzaj piśmiennictwa nie jest bezużyteczny, na przykład poruszając tematykę kryminalną, popularyzuje wiedzę o prawie.

109 Ibidem, s. 107-108.
} 
Baczyński S., Przedmowa tlumacza, [w:] G.K. Chesterton, Obrona niedorzeczności, pokory, romansu brukowego i innych rzeczy wzgardzonych. Z oryginatu angielskiego, z upoważnienia autora przełożyt Stanisław Baczyński, Towarzystwo Wydawnicze „Rój”, Warszawa 1927, s. I-IV.

Baczyński S., Syty Paraklet i głodny Prometeusz. Najmłodsza poezja polska, [w:] idem, Pisma krytyczne: Wyboru dokonat i wstępem poprzedzit Andrzej Kijowski, Państwowy Instytut Wydawniczy, Warszawa 1963, s. 130-160.

Baczyński S., Sztuka walcząca, [w:] idem, Pisma krytyczne: Wyboru dokonat i wstępem poprzedzit Andrzej Kijowski, Państwowy Instytut Wydawniczy, Warszawa 1963, s. 25-129.

Bujnowska A., ,, Stanisław Baczyński jako krytyk nowej sztuki”, Romuald Kanarek, ,Prace Polonistyczne” seria XL, (1985) [recenzja], „Biuletyn Polonistyczny” 1986, nr 29, s. 288.

\section{Opracowania}

[anonim], Baczyński Stanisław (1890-1939), [w:] Stownik współczesnych pisarzy polskich. Tom pierwszy $a-i$, red. E. Korzeniewska, Państwowe Wydawnictwo Naukowe, Warszawa 1963, s. 141-143.

Cegielski T., Detektyw w krainie cudów. Powieść kryminalna i narodziny nowoczesności 18411941, Grupa Wydawnicza Foksal, Warszawa 2015.

Chesterton G.K., Obrona detektywnych powieści, [w:] idem, Obrona niedorzeczności, pokory, romansu brukowego $i$ innych rzeczy wzgardzonych. Z oryginatu angielskiego, z upowaznienia autora przełożył Stanisław Baczyński, Towarzystwo Wydawnicze „Rój”, Warszawa 1927, s. $136-142$.

Dziemidok B., Czy sens i znaczenie współczesnej sztuki popularnej sprowadza się do jej wartości rozrywkowych?, „Estetyka i Krytyka” 2011, nr 1, s. 47-63.

Dziemidok B., Teoria przeżyć $i$ wartości estetycznych $w$ polskiej estetyce dwudziestolecia międzywojennego, Państwowe Wydawnictwo Naukowe, Warszawa 1980.

Jaworski S., Wstep, [w:] T. Peiper, Dzieła wybrane, oprac. S. Jaworski, Ossolineum, Wrocław-Kraków 1979, s. III-LXXX.

Kajtoch W., Bracia Strugaccy. Wydanie drugie, uzupetnione, Wydawnictwo Solaris, Stawiguda 2016.

Kajtoch W., Presymbolizm, symbolizm, neosymbolizm... Rzecz o czytaniu wierszy, Wydawnictwo Wojewódzkiego Ośrodka Metodycznego w Krakowie, Kraków 1996.

Kijowski A., Wstęp, [w:] S. Baczyński, Pisma krytyczne. Wyboru dokonat i wstępem poprzedzil Andrzej Kijowski, Państwowy Instytut Wydawniczy, Warszawa 1963, s. 5-23.

Krzyżanowski J., Rzędzian i Sherlock Holmes czyli o powieści detektywnej, [w:] idem, Szkice folklorystyczne, t. 2. W kręgu pieśni. W krainie bajki, Wydawnictwo Literackie, Kraków 1980, s. 191-200.

Lewandowski J., Wokół biografii Krzysztofa Kamila Baczyńskiego, [w:] idem, ,, Szkło bolesne, obraz dni...”. Eseje nieprzedawnione, Exlibris, Uppsala 1991, s. 1-19.

Stępień M., Obowiązek i prawo oceny (o Stanisławie Baczyńskim), „Zdanie” 2015, nr 3-4, s. 83-93.

\section{Stanisław Baczyński's theory of criminal novels}

\section{Summary}

Stanisław Baczyński (1890-1939), was the first Polish (and one of the first in Europe) literary critics to reflect on the popular genre of the criminal novel, and to look for the genesis and role of its transformation in social development. In the book Criminal Novel (1932), he points directly to 
the possibility of the novel's influence on construction of a hero in social views and moods. There is a link between the development of a democratic state and a criminal novel. A popular novel can help a citizen adapt to a new reality, a less classy and more democratic one. Moreover, in a modern society it performs a catharsis function, "it is a cure and, at the same time, an entertainment".

Baczyński's attitude towards the criminal novel was not Marxist, but it was the result of an avant-garde way of thinking, the result of the belief that a modern reality can be expressed in art only if the form of the artistic creation is changed. He believed that the artist who creates art of a new style fulfils a socially important task. Criminal fiction having a fast-paced plot, not very elaborate psychologism, and presenting the structures of a modern, democratic country, should make life easier for its readers who live in the 20th century. 